\title{
Grundtvig i politik op til 1830
}

\author{
Af Vagn Wåhlin
}

\section{Situationen 1830 og politikforståelsen}

Den hosstående tekst af Grundtvig »Politiske Betragtninger« blev af censuren frigivet til trykning d. 29. dec. 1830. Grundtvig har således kunnet nå at tage hensyn til flertallet af de væsentlige danske og udenlandske begivenheder i dette dramatiske revolutionsår: Karl X af Frankrigs antikonstitutionelle og antiparlamentariske reskript af 26. juli, - den påfølgende revolution i Paris og kongens flugt 2. august, Belgiernes opstand i samme måned og frigørelse fra Holland, - polakkernes opstand i Warzawa i november, men snarlige isolation og afmægtighed over for zarens tropper, - tilsvarende politiske uroligheder i en række mindre tyske stater m.v. I den dansk-slesvig-holstenske helstat vakte dønningerne fra Europa en i mange år ukendt politisk debat 1830 i klubber, aviser og pamfletter omkring to hovedemner: for det første, ønskeligheden af bredere borgerlig deltagelse i samfundslivet (politikken) gennem parlamentariske institutioner, for det andet, det af Uwe Jens Lornsens lille (12 s.) skrift »Ueber das Verfassungswerk in Schleswigholstein « nu synliggjorte nationale problem om Slesvigs statsretlige stilling mellem kongeriget og Holsten, dvs området fra Kongeåen til Dannevirke eller Ejderen eller hvortil?

Et tredje problem lå indlejret i debatten om et eventuelt repræsentativt politisk organ, i.e. andre borgerlige rettigheder, særligt omkring en præcisering af trykkefrihedens karakter og omfang. Emnet var centralt allerede i Pariseropstanden, fordi Karl Xs reskript betød så alvorlige indskrænkninger heri, at det kunne hævdes, at en generel censur, som under Napolen, var genindført. For Grundtvig, som da var idømt livsvarig censur efter Clausen-affæren, var dette emne naturligvis yderst relevant. I tiden og især få år senere omkring Frederik VIs vrede over 'skrivefrækheden' måtte borgerskabet selv tage affære herom ved dannelsen af Trykkefrihedsselskabet, dvs "Selskabet til Trykkefriheden rette Brug «.

Disse - og en række andre politiske emner, som tages op i Grundtvigs 1831-skrift - vil nedenfor blive diskuteret ud fra holdninger udtrykt mere eller mindre klart $\mathrm{i}$ hans tidligere arbejder, der her forstås på baggrund af en række (I-XIV) opregnede principper fra tidligere og samtidige europæiske stats- og samfundspolitiske teorier 
(herunder nogle af hans egne), som han direkte eller gennem tidsskriftlitteraturen har haft kendskab til - særligt fra England og kritisk i forhold til Tyskland og Frankrig. Grell, England (s. 16-17, m.fl.st.) viser f.eks., at Grundtvig i Verdenshistorierne, 1812 og 1817, demonstrerer indsigt i Hobbes', Lockes og Edm. Burkes skrifter og tænkning, - Lars Kaae (1986) har påvist hans kritiske holdning til tysk statsteoretisk tænkning og hans baggrund i ældre engelske opfattelser, især 1700-tallets »whig «-interpretation, og selv har jeg i den store artikel om Grundtvig og økonomien (1990) påvist, at han også har sat sig ind i fransk og italiensk samfundstænkning.

Det centrale i det efterfølgende er ikke at finde hvert frøkorn til Grundtvigs politiske tænkning, men at yde et bidrag til at sætte forskningen og debatten om Grundtvig som politisk væsen i perspektiv, og hertil tage afsæt i den foreliggende tekst.

Inden da må det kort fastslås, hvad jeg - og iøvrigt også Grundtvig - forstår ved politik og politisk virke. Med politik vil jeg forstå: en persons eller en gruppes fors $\emptyset \mathrm{g}$ på offentligt at påvirke den autoritative fordeling af de materielle og immaterielle goder, som har værdi i og for et samfund, - in casu, Danmark på Grundtvigs tid f.eks. jordfordeling og skattetryk som materielle goder/værdier og trykkefrihed og religionsudøvelse som immaterielle værdier (jvf. teksten [10] vedr. tyrannisk optræden). Med autoritativ forstås dét, som f.eks. staten og andre offentlige instanser fordeler eller sætter rammer for, mens privatsfæren og f.eks. familiens dagligliv i hovedsagen var uden for den politiske sfære - bortset fra visse rammebetingelser som f.eks. undervisningspligt og kirketugt.

Skønt Grundtvig ikke i 1831-skriftet - og iøvrigt heller ikke senere - direkte definerer sit politik-begreb, så ses det af skriftet og dets temaer, at han har en forståelse af politikkens genstandsfelt, som ligger nær op ad denne helt moderne opfattelse. Herved står han i modsætning til væsentlige tankegange fra samtiden og senere $i$ århundredet, ja helt til 1960erne, der mere lagde vægten på ideologien end fordelingspolitikken (del jer efter anskuelser) og indenrigsmassigt koncentrerede sig om politiske partier med tilhørende aviser, rigsdagsarbejdet og virket $\mathrm{i}$ kommunale organer samt over for andre lande på politikkens klassiske områder i udenrigs- og militærpolitik ${ }^{1}$. 


\section{Historiografi}

Skriftet »Politiske Betragtninger « har naturligvis været gennemset af forskellige grundtvigforskere, men har indtil 1993 været mærkelig lidt inddraget i studierne, skønt en række af de senere så markante grundtvigske synspunkter her for første gang lagdes frem offentligt $i$ mere samlet form. Selv så kyndige og grundige forskere som Helge Grell og Fl. Lundgreen-Nielsen har kun fundet anledning til at behandle skriftet $\mathrm{i}$ forbigående. ${ }^{2}$ Sidstnæunte bemærker i sin forbilledlige afhandling »Grundtvig og danskhed« (s. 12-13), at selvom 28. maj-forordningen 1831 om provinsialstænderne satte noget i gang, så var den offentlige debat til 1840erne i overvejdende grad finkulturel og teologisk og ikke samfundspolitisk. Den opfattelse har med baggrund i det 19. århundredes liberale og det 20. årh.s radikale historieskrivning også været dominerende blandt historikere, men holder dog kun for en kvantitativ og ikke for en kvalitativ analyse. Ud fra Grells og Lundgreen-Nielsens specielle synsvinkel i deres seneste afhandlinger kan en mindre grundig behandling forstås. Mere mærkeligt virker det, at forskere som Kaj Thaning (1949), Erik Møller (1950), Kaj Baag $\varnothing$ (1955), Poul Dam (1983) og Lars Kaae (1986) ikke nærmere har inddraget »Politiske Betragtninger « $\mathrm{i}$ en forståelse af Grundtvigs stigende engagement i samfundets forhold og udvikling, dvs i politik.

Først i 1993 blev 1831-skriftet taget op til nærmere behandling ud fra nogle helhedsforståelser af Grundtvigs livssyn og samfundstænkning. Tine Damsholt har i »Nornesalen« (1993) i artiklen »Kongehånd og folkestemme « set såvel de kontinuerte som de af af tid og udvikling forandrede træk i Grundtvigs samfunds- og politikforståelse med udgangspunkt i 1831-skriftet og den datidige situation. For mig at se med rette, tager hun afstand dels fra den udbredte opfattelse, at Grundtvig 1848 foretog en mental kolbøtte, dels fra den senere ophøjelse af Grundtvig i den grundtvigske bevægelse til det folkelige demokratis faderskikkelse (s. 52). Hun tager et fornuftigt afsæt i den norske historiker Jens Arup Seips forståelse af den »opinionsstyrede « enevælde ${ }^{3}$ som en herskende tankegang i brede kredse i Danmark og Norge fra sidst i 1700-tallet og i Danmark vel til en gang i 1830erne. Herefter slog mere demokratisk-parlamentariske opfattelser igennem sammen med en markering af de borgerlige frihedsrettigheder. I 1831-skriftet advarede Grundtvig imod de demokratisk-parlamentari- 
ske idéer, men tilsluttede sig en række af de øvrige borgerlige frihedsrettigheder, trykkefrihed, lighed for loven, etc. [39f,63]. Som det centrale i sit arbejde finder Damsholt, at Grundtvig i skriftet og ofte senere argumenterer for, at enevoldsmagten som hævet over klasseog partihensyn i handlingens dimension kan vælge det for helheden bedste ud fra en bred strøm af informationer formidlet via en fri offentlig debat på tryk, hvorudaf folkets ønsker ville fremgå. Den konstruktive vekselvirkning mellem »Kongehånd og folkestemme « som det poetisk formuleredes af Grundtvig $1839^{4}$ - er for Damsholt koblet til idéen om oplysning via en folkelig højskole og er:

»--- kernen i Grundtvigs folkestyreopfattelse, som er konsistent, og som han følger hele sit liv«. (s. 54)

For Damsholt må forskeren og Grundtvig selv altid tage tilbørligt hensyn til de mulighedsbetingelser, der er bestemt af den konkrete politiske og samfundsmæssige situation. - I resten af artiklen demonstrerer Damsholt med gode og velkendte eksempler fra Grundtvigs tekster fra 1830erne til 1850erne denne forståelses relevans. Sluttelig sætter hun igen højskoletanken om at uddanne og påvirke til menneskelig opvågnen og selvforståelse og borgerlig myndighed ind som et for Grundtvig nødvendigt led i hans politikforståelse, for at en fri »folkestemme « kan vinde frem i en afbalanceret samfundsudvikling.

Det andet større bidrag 1993 om 1831-skriftet er mit eget på engelsk, "Denmark Slesvig-Holstein and Grundtvig in the 19th Century «". For at forstå Grundtvigs mulighed for at slå bredt igennem som inspirator og folkelig leder $\mathrm{i}$ anden halvdel af det 19. århundrede, har det $\mathrm{i}$ artiklen været $n \varnothing d v e n d i g t$ at udrede de socio- $\varnothing$ konomiske forudsætninger derfor:

a) agrarsektorens dominans i den danske samfundsmæssige moderniseringsproces i 19. og op i det 20. århundrede og

b) gårdmandenes afgørende placering økonomisk og klassemæssigt, da de sad på ca. $75 \%$ af den dyrkede jord som enten ejere (1807 ca. $57 \%$ selveje, 1870 kun ca. $10 \%$ gårdmands-fæstejord tilbage) eller velbeskyttede gårdfæstere, og

c) politisk med gårdmændenes (men ikke de mindre husmænds) indflydelse stemmemæssigt og som valgbare fra 1834/35 til stænder- 
forsamlingerne, fra 1841 i kommunal- og amtsråd og fra 1849 i Rigsdagen, ${ }^{6}$

d) ca. $80 \%$ af befolkningen levede i Danmark på landet i 19. århundrede op til industrialiseringens og urbaniseringens gennemslag $i$ 1890erne; dette betød realistisk betragtet, at ingen andre grupper eller klasser i Danmark i længere tid kunne regere direkte imod gårdmændenes grundlæggende klasseinteresser.

Tillige bet $\varnothing \mathrm{d}$ disse socio- $\varnothing$ konomiske realiteter, at gårdmændene efter de store landboreformer fra 1788 og fremefter på deres 50.00070.000 gårde var blevet et solidt samfundsbevarende element og en agrar middelklasse, skønt det varede 2-3 generationer, inden godsejerne og Københavns borgerskab og akademikerne erkendte de nødvendige politiske og kulturelle konsekvenser heraf. Den sene enevældes centralstyre i København havde derimod klart set og med held arbejdet på at gøre »bondestanden«, dvs gårdmandsklassen og ikke landproletariatet, til statens stabile folkelige grundlag, jvf. Gr., Politik, [25]. ${ }^{7}$

Grundtvig fremlagde især efter englandsopholdene en stigende samtænkning af sine opfattelser af politikken og økonomien og koblede hertil dels sin folkelighedsforståelse, dels dennes - og hele menneskelivets - udfoldelse i den kristne dimension under Guds forsyn. Folket og politikken kunne for Grundtvig - og vel også for os ikke forstås og struktureres som meningsfulde størrelser uden i den tidsmæssige dimension, dvs. historisk. Men mange af elementerne i de herefter indbyrdes forbundne og indre vekselvirkende opfattelser hos Grundtvig af samfundet og politikken har deres klare forudsætninger før 1830 .

Inden vi går over til Grundtvigs opfattelser før 1830, må for læserne en fejl rettes i min anførte artikel på engelsk. Grundtvig er ikke, som det kan læses hos mig (Prophecy, s. 262), allerede 1830-31 inde på dén mulige løsning af nationalitetsproblemerne i hertugdømmerne at få Slesvig delt efter en sproglig linie og få dette bekræftet ved en slags folkeafstemning. Det er en overfortolkning fremkaldt af, at andre og Grundtvig selv allerede længe inden (i 1838) de sene martsdage 1848 var inde på sådanne konkrete løsningsmuligheder. Nedenfor kommer jeg nærmere ind på forholdet til Slesvig. Men det står fast, at Grundtvig allerede 1830/31 med bestemthed hævdede, at det 
var slesvigerne selv, som skulle afgøre sagen om deres nærmere nationale og statslige relation til Holsten eller til kongeriget Danmark:

»--- for mine Øjne var det naturligst at lade Slesvig eller Sønder-Jylland sige selv, til hvilken Side det helst gad hørt ---« [60]

\section{Politiske opfattelser for og i 1830}

I Grundtvigs samfundsforståelse efter 1830, som den klargjordes dels i en række småskrifter, dels i Mands Minde-forelæsningerne 1838 m. fl. steder og sluttelig fremlagdes som konkrete politiske synspunkter i Danskeren 1848-51 og på Rigsdagen, indgår en række elementer med en forhistorie i og for hans tænkning.

I de to anførte artikler »Danmark, Slesvig-Holstein and Grundtvig (1993)« og »Grundtvigs økonomiske tænkning (1990)« har jeg givet en socio- $\varnothing$ konomisk rammeforståelse for den danske samfundstilstands udvikling for at vise, at Grundtvig havde en særdeles realistisk opfattelse af de faktiske forhold i landet og i sin økonomisk-politiske opfattelse var på omgangshøjde med en række hovedtræk i samtidens europæiske politiske og økonomiske tænkning.

Grundlæggende for ham var, at et sundt samfundssystem og styre måtte bygge på en række pragmatisk begrundede opfattelser omkring:

I) Den primare produktion som grundlaget for livets og slægtens opretholdelse og videreførelse.

II) Arbejdet med både hånd og mund, dvs. materielt og åndeligt, som den centrale værdiskaber $\mathrm{i}$ et samfund. Heraf fulgte, at ikkeproduktive klasser var snyltere.[10]

III) Jord og klasser: I et agrarsamfund som det danske var jordfordelingen og de deraf afledte klasserelationer, der igen kunne føre til klassekampe og revolutioner, væsentlige.

IV) Storbyerne med deres voksende industrielle proletariat og deres kapitalistiske spekulanter og stigende antal advokater osv., som dominerede ærligt arbejdende håndværkere m. fl., var udtryk for en uheldig samfundsudvikling, der i det agrart dominerede Danmark endnu kunne undgås.

V) Egennytten var en menneskelig og social realitet som en form for drivkraft for menneskelig og social handling, der ved love og 
$\varnothing$ vrighed måtte begrænses, og som i en lang række forhold kunne modvirkes af en anden drivkraft, naestekarligheden eller blot »kærligheden«, når denne sidste blot fik frihed til at fungere (f. eks. omkring fattigforsorgen).

VI) Folkelighed var et essentielt element, hvor igennem et folk med fælles sprog, kultur, historie og landområde (herunder sans for naturens skønhed) formede sin egen nutid og fremtid i engageret vekselvirkning dels gennem egne indre muligheder (f.eks. økonomisk konkurrence under lige vilkår, folkekultur over for finkultur), dels udadtil over for andre folkeslag og lande med respekt for deres egenart.

VII) Magt og medbestemmelse: statslivet skulle være præget af et afbalanceret kontraktforhold mellem kongelig magt og folkets stemme - hvor den sidste blev udtrykt af en bevidst, indsigtsfuld og velovervejet, nærmest elitær offentlighed, hvori såvel samfundsmæssige realia som følelser og forventninger udtryktes for bredere befolkningslag.

VIII) Naturgivne rettigheder: Samfundets medlemmer havde nogle grundlæggende lige rettigheder til at virke for egen og samfundets lykke og velfærd, men havde ikke derfor i det daglige liv - og skulle heller ikke have - lige indflydelse eller lige social status. Forskel i det reelle liv måtte der være, men samtidig ønskede Grundtvig en bekræftelse på, at forskellene ikke førte til social udbytning, så at endemålet kunne blive et afbalanceret samfund, hvor »få har for meget og færre for lidt «.

IX) Frivillighed og offervilje: I samfundslivet, som over for familien i det nære - enhver måtte frivilligt ud fra en indre, ofte førbevidst holdning yde sit bedste og i sin yderste konsekvens være villig dertil med livet som indsats (krigen).

X) Friheds- og magtforståelsen: Grundtvig så samfundsmedlemmernes individuelle eller kollektive frihed som stående $\mathrm{i}$ et reciprokt forhold til samfundsmagten - i sine ekstremer anarkiet (socialt kaos, pøbelvælde) modsat tyranniet. Summen af frihed og magt i et givet samfund var konstant og kunne ikke vokse, hvorfor enhver ændring måtte ske ved, at nogle vandt, hvorfor andre tabte tilsvarende i frihed og/eller magt. Hverken frihed eller magt er for Grundtvig i den historisk-sociale virkelighed absolutte størrelser, men relative.

Friheden i trosforhold, økonomi (konkurrence) og »kultur« (skrivefrihed etc.), skulle i princippet for individet være total med visse 
rammelove til at hindre misbrug, dvs. at den enes frihed ikke medførte undertrykkelse af andres ligeberettigede frihedsområde. Politisk frihed derimod, måtte være begrænset. Friheden i folkelig eller national forstand er principiel og medfører for Grundtvig at ét folk, én stat, ikke må undertrykke andre. I den multinationale danske stat (både før og efter 1814) medførte dette, at et statsfælleskab kunne opløses og afløses af et nyt kontraktforhold, men ikke ved tvang, kun ved folkets, landets (in casu: Slesvigs) egen godtagelse af det fremtidige statsforhold (jfr. pkt XII). I Danmark havde man siden Struensees reformer haft trykkefrihed, der ved love fra 1790erne begrænsedes, dels ved en censors trykketilladelse, »imprimatur «, for mindre skrifter og artikler, dels ved et ansvar over for domstolene for statstruende, majestætsfornærmende, personligt ærekrænkende, embedsmandsfornærmende, usædelige m.v. udtryk og beskyldninger. For Grundtvig var netop trykkefriheden - og dens grænse - centrale, jfr. hans egen censurdom 1826/27

XI) Lighed og forskelle, socialt set. Den franske revolution havde med »frihed, lighed og broderskab « og afskaffelse af de arvelige privilegier sat lighedsproblematikken i centrum. Grundtvig fandt, at enhver kunne se, at ikke alle faktisk var lige kloge eller lige stærke, så at ulighed var en naturens orden. Hvad der derimod kunne tales om i menneskesamfundet var - i hver sin stilling - lige værdi og ret til at udvikle sine livsmuligheder, lige værd over for loven og, som et givet vilkår, over for Gud. Men i det konkrete samfund måtte der være forskel i indflydelse, afhængig af livserfaring, formue, begavelse og uddannelse.

XII) Samfundskontrakt og kongetroskab. Uden at diskutere det nærmere, må Grundtvig have overvejet de ældre europæiske tanker om »naturretstilstanden« som en forløber for det organiserede samfund, hvorudaf teorien om samfundskontrakten opstod - dvs. at de totalt frie individer frivilligt afgav magt til en autoritet for at modvirke de kaotiske følger af anarkiet ${ }^{8}$. Grundtvig accepterer som historiker, at stændersamfundet (præster, adel, bønder, arbejdende borgere og kongemagt/stat), havde skabt en vis orden i sin berettigede tidsperiode, men at folket som helhed mere med 1660 og arveenevældeakten, ved en ny samfundspagt, havde skabt en ny orden til helhedens bedste. Sålænge enevældens kongemagt undgik tyranniet og brugte magten til at forvalte riget ud fra helhedens tarv kunne befolkningen ikke ensidigt ophæve kontraktforholdet. Overholdt konge- 
magten ikke sin del af aftalen, var folket berettiget til at gøre oprør, men kun for at indføre en ny historisk og socialt begrundet orden, ikke permanent anarki - eller pøbelvælde, som Grundtvig kalder det. Når den enevældige konge udøver sin kongegerning til helhedens bedste på baggrund af nedarvede institutioner og folkets godtagelse, så bliver kongetroskab og fædrelandskærlighed egentlig to sider af samme sag.

XIII). Fadrelandskarlighed og modersmål. Til det land, hvor den konkret foreliggende befolkning boede, og for hvilket disses forfædre havde kæmpet, og hvis værdier var skabt af deres indsats, og gennem hvis fælles sprog forstandens, følelsen og troen erkendtes, oplevedes og formidledes, - til dette land udvikledes i den enkelte, i grupper og i hele folket en kærlighed, fædrelandskærlighed, som et indre bud. Udadtil måtte denne kalden omsættes i handling, og gennem modersmålet både inderliggøres og udbredes. Følelsen udtrykt i modersmålet blev forudsætning for og ikke behersket af den afbalancerede bevidsthed, hvor forstanden ellers kunne blive vildført af fornuftens logik (et opg ør med oplysningstidens fornuftsdyrkelse). Det mandlige og det kvindelige indgik herved i samfundsforståelsen som forskellige, men lige værdige og lige nødvendige dele af en menneskelig helhed i en løbende vekselvirkning.

XIV) Kristendommen. Skønt Grundtvig i sin samfunds-og politikforståelse engagerede sig i denne verdens forhold, så kunne han ikke som en relevant forestilling arbejde med et ikke-kristent Danmark og folk. ${ }^{9}$ Et menneskebegreb, et folkebegreb, et historisk begreb etc. uden at disse timelige forhold var indlejret $i$ og livgivet $i$ troens og det guddommeliges evige dimensioner var for ham ganske enkelt ikke rimeligt eller umagen værd at arbejde ud fra. ${ }^{10}$ Ret kristendom var en forudsætning for, at et folkesamfund kunne bestå og udvikle sig og kunne påtage sig sin universalhistoriske mulighed og forpligtelse for hele menneskeheden. Dette givne vilkår betød for Grundtvig ikke at man derfor ikke i dagligdagen og samfundslivets praksis kunne se f.eks. den konkret foreliggende kirkeinstitution, kirkernes bygninger etc., som »borgerlige « indretninger, der kunne have deres praktiske nytte som rammer for det for ham centrale: menighedslivet omkring tilbedelsen og sakramenterne mv.

Ovennævnte 14 punkter indeholder på langt nær alle væsentlige elementer i Grundtvigs samfundsforståelse og politiske tænkning, og 
vil helt naturligt ofte omkring faktiske historisk-samfundsmæssige forhold overlappe hverandre For Grundtvig fandtes visse få samfundsmæssige grundprincipper, en slags sociale naturlove, f.eks. ejendomsrettens princip, respekt for historisk grundfæstede samfundsrelationer, den individuelle friheds relative begrænsning af love og autoriteter, Guds forsyns indgriben, enhvers ret og pligt til ved egen indsats at forsфrge sig og sine, - disse grundregler for samfundslivet var forud givne og kunne ikke frit ændres af samfundet selv. Inden for disse rammer var det den historisk og socialt foreliggende situation, der politisk-samfundsmæssigt skulle handles ud fra, og ikke ud fra nogle af den menneskelige fornuft opfundne doktriner - i den forstand var Grundtvig pragmatiker mere end konservativ.

Samfundets virke og styrelse skulle i sidste ende foregå ud fra overordnede hensyn til hele folkets velfærd. For det første krævedes hertil evne og vilje til etisk og moralsk at afveje og handle i det konkrete ud fra et sådant helhedssyn, som i menneskelivets hverdag ville stå over for de mange enkelte eller forenede udtryk for egennytten, egoismen. For det andet krævedes hos de styrende en solid viden om historiske forudsætninger og det yderst komplekse - og sig hastigt ændrende - mønster af samtidige forhold og betingelser. Skulle folket ved dets elite, og måske med tiden bredere ud, påvirke eller deltage $\mathrm{i}$ styret, så krævede det indsigt og oplysning foruden mulighed for at kunne se ud over snævre stands-, klasse- og egeninteresser. I sidste ende drejede det sig her om i samfundsmæssig forstand at kunne sætte hjertet (følelsen) forud for forstanden og kærligheden forud for egennytten, - uden derfor at fornægte hverken forstandens eller egennyttens faktiske forekomst eller berettigede funktion i menneskelivet, f.eks. i den økonomiske konkurrence.

\section{Udviklingstrak i Grundtvigs politisk-samfundsmaessige tankning}

\section{Lighed og frihed}

Ifølge mindedigtet ved Henrik Steffens' død 1845 blev Grundtvig, som andre ved Steffens' forelæsninger 1803 og antagelig også ved 
slaget på Rheden 1801, vakt af en dødlignende søvn [4. strofe, ln. 5; 5. strofe, ln. 1-2]:

»---Ordet, som af Aanden føres, / Skaber Lyn, hvor Røsten høres, / Vaagned Steffens, her med dig! / Folket sov som Lig i Kiste, / Kæmper sov som Kampesten; / (Gr. Udvalgte Værker, I, s. 400).

Europa befandt sig under den franske revolution i et dramatisk tidsskifte, men til 1801 var ulykkerne gået uden om landet. En indre vækkelse måtte til før de unge for alvor kunne engagere sig; det var bl.a. Steffens' indsats for Grundtvig og mange andre. Skete det ikke lige da og på én gang ${ }^{11} 1801-3$ for Grundtvig, at han seriøst begyndte at tænke over samfundsforhold og om sit forhold til det danske (han har ikke helt styr på tidsforholdet), så står der følgende at læse i hans dagbøger under 1804 om det for en politisk forståelse så vigtige lighedsbegreb fra tidligere europæisk statsretlig tænkning og de amerikanske og franske revolutioner:

»Fuldkommen Lighed er en Sjimære ${ }^{12}$---. En saadan Lighed, at ingen Borger arver Prærogativer, men blot ved sin højere Sjæls Fortrin, ved sin fortjente Stilling i Staten, ved sine specielle Fortjenester faar Ret til udmærket Agtelse. - Saadanne aristokrater skulle kun da eksistere.« (Dagbøger I, s. 92).

I 1790'ernes København ironiserede Abrahamson over uligheden i samfundet med »Ordener hænge man paa Idioter« $\mathrm{i}$ visen »Hvermand i Byen om Indtoget taler «. I den i Europa meget diskuterede Amerikanske Uafhængighedserklæring fra 1776, fastsloges i selve den principielle indledning dels folkets suverænitet, dels at alle mennesker var født frie og lige og havde en umistelig ret til at stræbe efter indkomst og lykke tillige med religionsfrihed mv., ligesom tilsvarende opfattelser gik igen i den franske revolutions forfatninger og i de vedtagne menneskerettighedserklæringer, 1789.

Grundtvigs tvivl 1804 om lighedens generelle mulighed og ønskelighed - bortset fra lighed i muligheder og lighed for loven - viser sig i "Politiske Betragtninger « flere steder, f.eks. $[18,19]$ hvor han sammenligner samfundet med en stor gårdmandsfamile, hvor alt ville gå galt, hvis børn og tyende og sågalt husdyrene alle var lige til selv 
at bestemme, hvad de ville, - og langt værre blev noget sådant ligemageri for ham på statsniveauet.

På de samme sider [17-20] tages friheden/magtcentreringen (ovenfor, pkt. X) op med historiske eksempler fra oldtiden til Napoleon på, at en socialt for udstrakt frihed - og ekstremt i revolutionernes pøbelvælde - fører over i sin magtmæssige modsætning, tyranniet og diktaturet, hvor netop alle frihedsrettigheder, og herunder trykkefriheden, undertrykkes [23]:

»(I statsforfatningen --- ) der maa Man lægge Baand paa disse Yndlinger (de politiske friheds- og lighedsbegreber, V.W.) istedenfor at løslade dem, hvis de ikke skal forstyrre og ødelægge Alt.«

\section{Fadrelandskarlighed og frivillighed}

Historien og fædrelandskærligheden er hos Grundtvig vævet sammen, så at det fædrene land kun har mening $\mathrm{i}$ et historisk perspektiv, hvor den enkelte og en generation knytter an ikke blot med forstanden, men også med følelsen til det land, som forfædrene har skabt og kæmpet for. Tilbage til Saxo og 1600-tallets adelsslægter, men i den her relevante form fra 1700-tallet, suppleres den feudale fyrsteloyalitet, der passede godt til den internationaliserede højadel i oplysningstiden, med en patriotisme, fædrelandskærligheden. I de højeste kredse udtryktes dette, f.eks. ved Chr. VII's valgsprog »Gloria ex amore patriæ«. Væsenligt er her, at der er tale om en identificering, som følges op af en frivilligt påtaget forpligtelse til at gå fra talens til viljens og handlingens dimension - ikke blot hos en edsforpligtet embeds-og officerselite, men også bredere ud i borgerlige kredse hos håndværkere og måske bønder. ${ }^{13}$

Hos Oehlenschläger og den unge generation af digtere slog opfattelsen af middelalderen som en guldalder at søge forbillede i igennem, og naturligvis var Grundtvig påvirket heraf, både i tænkning og i praktisk fædrelandskærlighed. Han og Oehlenschläger var f.eks. begge medlemmer af det militære studenterkorps. Men hvordan stod Grundtvig for offentligheden frem med synspunkter herom? Efter linieskibet, Prins Christian's kamp mod en engelsk eskadre og ødelæggelse 1808 ved Sjællands Odde, hvor søhelten Peter Willemo- 
es omkom, arbejdede Grundtvig med dette tema i flere udgaver, hvoraf to er vigtige: på bestilling skrev han indskriften for de faldne på mindestøtten på Odden kirkegård, mens det andet arbejde var digtet om Willemoes.

Oddenstøttens 2. strofe: ${ }^{14}$

»Her er jeg sat til en Bautasteen

At vidne for Slægter i Norden

Danske de vare hvis møre Been

Under mig smuldre i Jorden

Danske af Tunge, af Æt og af Id

Thi skal de nævnes i løbende Tid

Fædrenes værdige Sønner.

Digtet er sat på en klassisk inspireret mindesøjle - hvilket Grundtvig ikke kan klandres for - men han vælger bevidst i stedet for det mundrette og samtidige $»$ mindesten « at benytte det oldnordisk klingende »Bautasteen «. Som i 1. strofes »Snekker« og »Kvæld« fastholdes den oldnordiske tone og dermed den historiske dimension. Udover at have kæmpet heltemodigt, hvad karakteriserede da kampens døde: de var danske, og de var danske af sprog og danske af herkomst og danske i handlingens dimension. I næstsidste linie kunne Grundtvig have benyttet ordet »kommende«, men skriver »løbende«, som giver indtrykket af tiden som en strøm, hvor fortid-nutid-fremtid knyttes sammen $i$ et forløb. I sidste linie kunne Grundtvig have valgt flere positivt beskrivende tillægsord, f.eks. »brave« eller »modige «, der i almindelighed ville knytte godt an som beskrivende de omkomne $i$ et slag. Men han skriver »værdige «, hvorved han igen fører læseren bagud til dem, fædrene, som tidligere har kæmpet for samme sag: Danmark. Sidste linie kunne altså have lydt, »Dannemarks modige sønner«, og kunne så i sin direkte tale være skrevet af Thaarup eller en anden lejlighedsdigter. ${ }^{15}$

Læseren må tilgive en historiker denne frihed over for et af dansk litteraturs fornemste nationale digte. Men hermed mener jeg at have begrundet, at allerede 1808-10 beherskede Grundtvig de nationalpolitiske og objektive grundbegreber for et folk, det danske:

fælles historie,

fælles landområde

fælles sprog 
og lagde dette offentligt frem. Hertil kom den opfattelse, at begreber som danske mv. i sig selv for ham intet var værd, hvis de ikke fulgtes op i handlingens dimension, »Id «, helt til den yderste konsekvens med livet som indsats.

Willemoesdigtet ${ }^{16}$ og Odden-digtet er skrevet tankemæssigt og tidsmæssigt parallelt. I Willemoesdigtets 20 stofer benyttes ordet »snekke« syv gange, »Christian « (linieskibet) tre gange, mens skib kun benyttes en gang, og da om dem, som englænderne opbragte. I stofe 18 hedder det $\mathrm{i}$ de tre sidste linier: »Over dine Kjæmpebeen/ Rejse vi en Bavtasteen/ Give Steenen Mæle:«, hvilket både i ordvalg og faktisk indhold viser hen til Odden-digtet. Den engelske Royal Navy kaldes (strofe 15) for »Bretlands Viking «, her nærmest i betydningen sørøver, og det hævdes i strofen, at havde den danske flåde været kampklar og med søofficerer som Willemoes, da var begivenhederne i 1801 og 1807 næppe gået så godt for englænderne. Men ellers er der intet nationalt had over for englænderne, ingen hævntanke at spore i digtene, kun sorgen over tabene. ${ }^{17}$

Syvende strofe lyder:

»Sælsomt i hans Aand det lød:

»Hører du det dønner!

Dannemark er stedt i Nød,

Kalder sine Sønner«.

Og som gamle Danmarks Søn

Fløj han mod det hule Døn,

Fædreland at værge«. (Udvalgte Værker, I, s. 195)

Sønner og fædre/fædreland er her, som i sidste linie af Odden-digtet knyttet sammen. Men det væsentlige er den sælsomme »indre stemme«, som byder ham at komme hjem og deltage i fædrelandets forsvar. Det var ikke en ordre af kongen, han modtog (for så havde det stået der), men netop en indre kaldelse, hvor det danske i ham ligesom ubevidst førte til hans frivillige tilbagekomst; strofe 14 nævner hans ophold i udlandet, han var med tilladelse på vej til tjeneste i Ruslands flåde. Skønt matrosernes flertal på »Christian « var norsk, ${ }^{18}$ synes der her endnu ikke for Grundtvig at være nogen national forskel på danske og norske. De var fælles i det nordiske ophav og endnu 1810 i den faktiske stats historie fælles gennem mere end 400 år. Efter 1814 og Eidsvold-forsamlingen, hvor nordmænden- 
de demonstrerede en klar vilje til national selvstændighed, skiftede Grundtvigs sympatier for Norge en tid. ${ }^{19}$

Kongen, indtil 1808 kronprinsen, Fr. VI, nævnes ikke med ét ord eller ét symbol (f.eks. kronen) i Willemoesdigtets 20 vers, ej heller på Odden-støtten, mens Danmark, danske, Dannebrog, fædreland dvs. folk og land og symbolerne derfor - alene i Willemoesdigtet nævnes mindst 11 gange. Denne manglende nævnelse af kongen eller et symbol for ham kan ikke være nogen tilfældighed, når man tager tidens ofte ekstreme kongeloyalitet og kongedyrkelse i betragtning, jvf. f.eks. også de normalt udeladte sidste strofer af Grundtvigs digt »Langt højere Bjerge $\ll^{20}$, hvor kongerøgelsen svæver tykt.

Den indre danske stemme hos Willemoes til ansvarlighed i frivillighed viser i sin moralsk-etiske dimension hen mod en folkelig forståelse hos Grundtvig - selvom folkelighedsbegrebet i politisk forstand først fuldt udfoldedes fra 1830'erne.

Med den romantiske bevægelse delte Grundtvig de ydre kriterier for et folk: fælles landområde, fælles historie, fælles sprog og kultur. Det væsentlige er i de to digte dels det handlingsmæssige imperativ, ikke på ordre, men frivilligt ud fra et påtaget ansvar, dels i Willemoesdigtet mildheden og poesien (sangene og de unge piger) samt blomsterne på forårets enge, der som helhed viser hen til en kærlighedens dimension.

Endnu et element fra Willemoesdigtet må nævnes, idet Grundtvig i 4. stofe anfører, at det var i handlingens og kampens virkelighed at drengen (den helt unge søofficer, Willemoes) tog sit ansvar på sig, først som helt, derefter som mand, men uden at miste sin barnlige åbenhed og charme (strofe 5 og 6). Den umiddelbare overgang $\mathrm{i}$ strofe 7 til at høre og adlyde den indre stemme kunne hos Grundtvig være en antydning af, at for meget forstand kunne lukke for hjertets danske stemme.

Hermed mener jeg at have argumenteret for at Grundtvig allerede inden arbejdet med Verdenshistorien $(1812,1817)$ og Danne-Virke (1816-1819) havde og offentligt udtrykte en samfundsmæssig-politisk mening om så væsentlige sager som historiens betydning, danskhed og folk (VI) om karlighed som et element i sociale handlinger (V), om frivillighed og offervilje (IX), om fadrelandskarlighed og modersmål (XIII) - dvs. en række centrale elementer i hans senere fuldt udviklede folkeligheds- og politikforståelse. 
Med baggrund i de ulykkelige følger for Danmark med afslutningen på krigene, statsbankerot 1813 , tabet af Norge 1814 osv. udfærdigede Grundtvig 1815 under Napoleons 100 dage (marts-juni), der endte ved Waterloo, skriftet, »Europa, Frankrig og Napoleon, En dansk historisk Betragtning «. Napoleons nederlag og tilfangetagelse skete d. 22 juni, så da Grundtvigs skrift endelig udkom 5. juli, var det mildest talt uaktuelt vedrørende fremtiden. Heri havde Grundtvig udtrykt håb om, at Napoleon kunne repræsentere den afbalancerende magt i Europa, og derved fungere som en »fredsfyrste « efter snart en menneskealders revolutioner og krige. ${ }^{21}$

Det væsentlige er her ikke at Grundtvig tog fejl vedrørende Napoleons magtmuligheder og krigslykke ved Waterloo, men Grundtvigs historisk-politiske vurderinger bl.a. omkring et »jernscepters « (Napoleons) [6] historiske nødvendighed, når revolutioner havde rystet samfundene og staterne. I det lange historiske perspektiv ser Grundtvig i skriftet Romerrigets fald og de germanske folkestammers konstruktive islæt $\mathrm{i}$ skabelsen af middelalderens nye storriger $\mathrm{i}$ Frankrig, Spanien og Italien. En åndelig kraft er tilbage til at grundlægge nye storriger, hvor hjertesproget fandtes renest og bedst bevaret, dvs. i Danmark og hvor:

»Det danske Folk er det eneste, som gjennem Aartusinder har bevaret sig og sit Sprog og sine Fædres Minder, er aldrig oversvømmet af fremmede Folkefærd--- ${ }^{22}$

Både på dette sted og sidst i 1815-skriftet, ligger det indlejret i og er åbent udtrykt, at gennem det danske, fordi det er rent - dvs. ikke historisk og sprogligt opblandet - vil det guddommelige vise sig i og bag det historisk-statslige:

»Roms Aand skal falde for Danmarks Engel, Ordet skal paa Danmarks Tunge overvinde Antichristen med al hans Kløgt og Trolddom ${ }^{23}$

Igen ser vi her historien, sproget, landet, kulturen og folket knyttet sammen og rent bevaret, bl.a. fordi danskerne - vel i stædigt selvforsvar - ikke blev undertvunget af fremmede »Herrestammer«. Væsent- 
ligt, som andre steder i Grundtvigs skrifter, er det, at det guddommelige er koblet til folkelivet, og at det, på Grundtvigs tid, var Danmarks (og Nordens) skæbne at stå for ikke blot sin egen, men menneskehedens fremtid [7-8]. ${ }^{24}$

Det centrale er, at koblingerne mellem det timelige i historien, sprog, land og folk allerede længe før 1830 synes meningsløst for Grundtvig uden den moralsk-etiske dimension og anknytningen til det guddommelige i kristen forståelse, jvf. ovenfor pkt. XIV, [23-].

Det hører med til den romantiske forstålse at se det guddommelige i hele tilværelsen og universet. I digtet »Strandbakken ved Egeløkke « trykt 1811, afviser Grundtvig i 5. strofe som forstandens blændværk »Vittighed, Klogskab og Kulde«, og takker i stedet for, at han som en nådesakt:

"Fandt, hvor det faldt/ Gud overalt:/ Fandt ham i Digterens Sang/ Fandt ham i Vismandens Ord,/ Fandt ham i Myter fra Nord,/ Fandt ham i Tidernes Gang;/ Synligst og vissest den dog/ Fandt ham i Bøgernes Bog.« (Udvalgte Værker I, s. 307308).

Om frihed, oprør og ejendom.

I 1816 skrev Grundtvig i Danne-Virke:

»---thi fødte Trælle kan kun ved Lydighed vorde frigivne, og ære Oprørere, naar de vil sætte sig selv i Frihed, hvilket ei kan skee uden ved at undertvinge Fribaarne og giver ingen Eiendom, men ikkun Rov. ${ }^{25}$

Ejendomsretten er her sat så centralt, at den endog overgår individets (slavens) ret til personlig frihed, med mindre friheden frivilligt skænkes slaven af ejeren. Ejendommen er det, som lovligt og ved arbejde erhverves, mens oprør i sig selv er fordømmeligt, i hvert fald på det individuelle plan. Man genkender fra 1831-skriftet Grundtvigs tidligere afstandtagen fra revolutioner (grundoprør) [5-11], men ser, at han i 1830 på det samfundsmæssige plan skelner mellem berettiget oprør mod tyranniet (f.eks. grækernes oprør mod tyrkerne 1820) og forkastelige revolutioner [10-11]. Sammesteds [10] ses hans frem- 
hævelse af »Frugterne af deres Flid« som det, der ikke må fratages folk, altså ejendomsretten til det nyttiggjorte og arbejdets resultater (jvf. ovenfor I og II).

Samtænkningen hos Grundtvig af ejendomsrettens samfundskonstituerende betydning - og vel at mærke den ejendom, som er lovligt erhvervet - og truslen herimod ved revolution eller menneskets tagen sig selv til rette ses af eksemplet [24]. Dette sted hos Grundtvig viser, at slaven ikke kan blive fri, uden at ejeren mister noget - frihed og magt (over andre) er altså gensidigt afhængige (jvf. ovenfor X). Frivilligheden (IX) fra ejerens side må ind i billedet, der i øvrigt hos Grundtvig som forudsætning har det mest ekstreme i social forskellighed (VIII og XI), den mellem herre og træl.

\section{Frihed fra $n \varnothing d$, borgerlig frihed og religiøs frihed}

I lejlighedsdigtet »Danmarks Trøst«, 1820, ved skibet Pram's afrejse til Ostindien, »Langt højere Bjerge---« karakteriseres det danske som jordnært og venligt. Sproget er blidt, og i strofe 4 ln. 3-6 hedder det:

»Hos Dansken dog findes det daglige Brød/ Ej mindre i Fattigmands Hytte,/ Og der har i Rigdom vi drevet det vidt,/ Naar Faa har for meget og færre for lidt./«

Til slut æres kongeslægten og Fr. VI. Her opstilles et ideal om, at uligheden i samfundet ikke må gå for langt, og at det skal sikres, at selv de fattige har tag over hovedet og mad på bordet, jvf. VII og XI.

Efter censurdommen 1826/27 udgav Grundtvig i 1827 to principielle skrifter, »Skribenten Nik. Fred. Sev. Grundtvigs Literaire Testamente« og en artikel, »Om Religions-Frihed « (Udvalgte Skrifter, V).

I Testamentet er Grundtvig bl.a. inde på, at hans sammenkædninger af nordiske, historiske og kristelige »ånder « har fået mange til at forkaste helheden hos ham på grund af afstandtagen fra enkelte elementer. Fremover vil han derfor prøve at adskille enkeltelementerne, for at lade læserne frit vælge, hvad de kan bruge (L. Kaae, 80). Selvhævdelsen og selvtilstrækkeligheden [23-24], havde domineret i 1700-tallet, så at »alt Fællesskab kun var til Byrde, ei til Trøst«. For at samfundene ikke skulle gå til grunde måtte der, for Grundtvig at 
se, skabes frihed for borgerne, så de kunne inddrages i debatten om og skabelsen af samfundet såvel i ord som i gerning.

I artiklen om religionsfrihed mener Grundtvig med baggrund i engelske forhold, at en fuldstændig religionsfrihed er nødvendig vedrørende »menneskets Aandelige Natur og Bestemmelse«, selvom man godt med fordel kan have en statskirke. I en sådan kan man $\mathrm{i}$ stedet for offentligt ansatte pastorer have veluddannede præster i fri konkurrence, der:

»---anderledes flittig arbeide paa, ved kraftig og kjærlig Undervisning (fra prædikestolen V.W.) at knytte baade Gamle og Unge aandelig til sig og til den fælles Tro ${ }^{26}{ }^{26}$

Samfundsmedlemmerne skal altså inddrages i et konstruktivt engagement i samfundsudviklingen, dvs. tænke og agere politisk - hvilket forudsætter i hvert fald trykkefrihed for at kunne realiseres. Selv i kirke- og menighedsliv burde, efter Grundtvig, en gavnlig konkurrence indføres. Dette kræver en grundlæggende frihed i trosforhold, jvf. VII og X.

\section{Rigsdagene}

For Grundtvig er det allerede før 1830 vigtigt, at mennesket som ansvarsbevidst borger tager medansvar for samfundets tarv, jvf. forrige afsnit om bl.a. borgerlige friheder og ansvar. Skønt han bl.a. i skriftet om Europa (1815) har negative bemærkninger om det repræsentative styre i Frankrig, har jeg ikke fundet at han med klarhed har udtrykt sig om parlamenter og rigsdage som positive/negative udtryk for folkestemmen før her i 1830. I Grundtvigs breve til hustruen (1829-31) fra englandsrejserne bemærker han under 10. juni, dvs. før juli-revolutionen i Paris, at han har været i Underhuset for fra galleriet at følge parlamentsdebatterne, som åbenbart ikke har gjort det store indtryk på ham. Den 11. august s.å. har Grundtvig været til valgmøde i anledning af det udskrevne parlamentsvalg og var endnu $\varnothing \mathrm{m}$ efter de knubs, han fik i trængslen omkring de to parlamentskandidaters opstillingsmøde. Den 18. august bemærker han, at valgene til parlamentet ofte sker imod ministrenes $\varnothing n s k e, ~ o g$ det forestående valg finder han særligt uheldigt under hensyntagen til 
de revolutionære forhold i Europa [26-39]. Først den 28. maj 1831 fremlagdes den danske regerings mønster for en folkerepræsentation, der var rådgivende, og som $\mathrm{i} h \varnothing \mathrm{j}$ grad tog hensyn til de faktiske klassemæssige forhold. Men allerede i november 1830 havde kongen i forbindelse med en proklamation om Uwe Jens Lornsens fængsling $i$ vage vendinger meddelt, at regeringen påtænkte at indføre nye konstitutionelle forhold i riget. Dette hang sammen med pres på den danske regering fra den tyske Forbundsdag og Preussen i september og oktober, og i januar 1831 kom den første proklamation om regeringens tanker herom.

Grundtvigs andet hovedafsnit i 1831-skriftet er et indlæg i debatten om en eventuel repræsentativ forsamlings udformning. Bl. a. med baggrund i hans historiske studier ${ }^{27}$ og erfaringer ved selvsyn i England i 1829-30 fra Parlamentet og ved studier i den franske nationalforsamlings rapporter samt almen historisk viden opregner han [2839] de fremførte hovedgrunde for den parlamentariske forsamlings nytte som et positivt udtryk for folkets $\emptyset$ nsker. Dernæst gendriver han disse opfattelser punkt for punkt dels med konkret baggrund i den rimeligt velfungerende danske enevælde - i forhold til hele folkets velfærd - dels med baggrund $i$, at menneskers egennytte og uforstand gennem klasseinteresser og partier vil gøre sig gældende både ved valgene og i et parlaments arbejdet [29-31].

Den etiske styrke i en udviklet fædrelandskærlighed [31], (jvf. ovenfor, XIII og afsnit »Fædrelandskærlighed og frivillighed «) har i Danmark fungeret positivt. Man bemærker her atter [21-22], hvorledes den danske godsejer hævdes at bestyre sit gods med henblik på såvel de undergivnes velfærd som den fremtidige nytte, mens omvendt den angelsaksiske kapitalistiske fabrikant er kortsynet og umenneskelig i sin udbytning af fabriksarbejderne, dvs. at fabrikanten bryder både budet om medmenneskelighed og Grundtvigs udtalte $\emptyset$ nske om at undgå for stærke sociale forskelle; punkterne ovenfor IV, V, IX, XI og XIII indgår faktisk heri. Afsnittet om stats økonomi [32-35] er væsentligt og nyt i forhold til, hvad jeg ellers har fundet hos Grundtvig forud. Det centrale ligger antagelig i, at han bl.a. fra Englands Parlament har set, hvorledes råderetten over budgetterne, skatterne og pengenes bevilling er et centralt element i parlamentets magtudøvelse. Heraf fulgte korruption og politisk nepotisme [37] og, antager han [34], bortskæring af kulturelle og kirkelige (gudelige) udgifter, hvilket vil medføre en efter hans mening uheldig akulturel 
stat. En stærk konge kan efter hans mening bedre vælge gode rådgivere [36], end en rigsdag kan finde gode ledere. En partipolitisk orienteret rigsdag vil ikke normalt få de bedste kræfter frem på de rigtige lederposter. Endelig gør Grundtvig [38-39] op med en konstitutionel konges subvensive veto. Vetoet kan muligvis forhindre visse politiske dumheder, men det kan ikke sætte nogle konstruktive love eller tiltag i stedet.

Til stadighed er det historiens lære og de konkrete parlamenters og rigsdages virke han henviser til, mens statsteorierne afvises [26-27] som fornuftens »Blændværk «.

Hans stands- og klassesyn er også historisk og praktisk dikteret [35-36]. Det middelalderlige stændersystem havde, efter hans mening, sin berettigelse, men det er tydeligt, at magtcentreringen hos et enevældigt styre stadig på hans tid sikrer flertallet den højeste velfærd udfra helhedens tarv.

Både i afslutningen af første del [25] og i anden del [35] fremdrager Grundtvig det forhold, at der bør tages hensyn til den danske bonde (gårdmændende), som i forhold til andre landes almue er bedre oplyst og er et socialt stabiliserende element i samfundet.

Rigsdag og parlamenter er for ham ikke den rette vej for de styrende til at kunne kende »Folkets Stemme«, men hvordan skulle de styrende ellers få kendskab til, hvad der rørte sig i befolkningen?

\section{Skrivefriheden}

Da repræsentativt-parlamentariske forsamlinger af Grundtvig måtte afvises af mange grunde, blev der for ham at se tilbage at inddrage »Folkets Stemme«, den offentlige opinion udtrykt på skrift, jvf. ovenfor, X, om frihed og magtforståelse. Men også med trykkefriheden var der et væsentligt problem, idet netop aviserne i Paris havde været centrale i og uansvarlige omkring juli-opstanden 1830 [13-14]. Skrivefriheden i politisk sammenhæng måtte derfor have sine grænser i en »velordnet Skrive-Frihed « [41], men ville så i $\varnothing$ vrigt kunne formidle til de styrende, hvad folket $\emptyset$ nskede, og de bedst skrivende blandt en uddannet elite formulerede. Egentlig skulle det være nok, mente han, at en anerkendt boger på mere end 40 år ved sit navn trykt som garant på skriftet ville sige god for de unges og de ikke dannedes skriftlige arbejder, så burde samfundet have den nødvendige 
kontrol. Med »dannelse« vil Grundtvig forstå, at man ikke kun skal reservere skrivefrihed til klassisk skolede akademikere, men han tænker også på en folkelig og borgerlig dannelse [50-51].

En sådan dannelse for ikke-akademikere forudsatte en »Hфiskole for folkelig Videnskabelighed og borgerlig Uddannelse«. Dette er interessant, for her knyttes en ikke-akademisk voksenuddannelse sammen med borgerlig myndighed og politisk indflydelse via en højskole. Jeg skal ikke her gå nærmere ind på eventuelle forbilleder for Grundtvigs tanker herom, f.eks. University College, London. ${ }^{28}$

\section{Danmark, Slesvig og Holsten}

Grundtvig selv kunne godt forstå, at holstenerne, som udtrykt i diverse skrifter 1830, ikke ville være danske [57], ligesom han meget ville have sig frabedt at være tysk. Derfor er det ud fra hans tanker om folk, historie og sprog (jvf ovenfor, VI, folkelighed og XIII, fædrelandkærlighed) en logisk konsekvens, at holstenerne, som tyskere, måtte bestemme deres egen vej under henvisning til Wienerfredens $\S 13$ fra 1815 , som det måtte formodes, at den ordholdende konge, Fr. VI, nu ville sætte i kraft. Anderledes og mere problematisk var det med det folkeligt delte Slesvig [59-61]. Et slesvigsk parlament til at afgøre tilhørsforholdet fandt Grundtvig, jvf. forudgående afsnit, helt uacceptabelt. Uwe Jens Lornsen havde i sit anførte skrift foreslået en grundlovsstiftende nationalforsamling samlet for begge hertugdømmer, hvilket Grundtvig end ikke besværede sig med at afvise. Ligeledes var Grundtvig ikke meget for Lornsens forslag om bønskrifter, petitioner, om sagen til kongen.

En skriftlig afstemning i alle egne af Slesvig i fremlagte protokoller fandt han umulig, for »alle Næver paa Skaft, selv, eller med paaholden Pen«. Eftersætningen til forslaget om en form for folkeafstemning er vigtig, fordi det heraf fremgår, at det er det praktiske med manglende skrivefærdighed, han fremhæver og ikke, at det var en forkert måde at udfinde folkets stemme på. Tilbage bliver derfor for Grundtvig, som ovenfor, en offentlig menig formidlet af:

»De Slesviger der har lært at skrive, til, under deres Navn paa Prænt, at sige deres Mening kiønt« [60]. 
Af historiske grunde og ud fra egne samtaler med slesvigere antog Grundtvig dog, at slesvigerne ville foretrække et nærmere fællesskab med Holsten. Det centrale var, at de fik lejlighed til at valge selv. Vedrørende Uwe Jens Lornsens virke og skrift er det værd at bemærke, at stormagternes indgriben over for Danmark vedrørende at give Holsten en stænderforfatning, var sket inden Lornsens fremtræden. Efter en rundrejse i de sidste dage af oktober i Slesvig måtte Lornsen konstatere, at han ikke havde fået megen støtte til sine konstitutionelle tanker. Først på et møde 1. november i Kiel med 3040 liberale, advokater og borgere, besluttedes det at offentliggøre hans lille skrift, der tryktes i 10.000 eksemplarer. 16. november greb regeringen ind med den anførte offentlige proklamation i to led. 1 . Et løfte om at gøre noget ved hertugdømmernes forfatningsformer ${ }^{29} .2$. En arrestordre på Lornsen. Denne fængsledes 23. november og blev 31. maj $1831 \mathrm{~d} ø \mathrm{mt}$ til at miste sit embede og et års fængselsarrest. I fængselstiden fortsatte Lornsen sine teoretiske overvejelser og kom herunder ind på at løse nationalitetsproblemet i Slesvig ved at lade en strimmel at det nordligste Slesvig overgå til kongeriget. ${ }^{30}$

Syndikus Carl Frederik Herrmann Klenze (1795-1878) svarede i en pamflet 1830, som Grundtvig havde læst og fundet rimelig, på Lornsens flyveblad. Klenze var uenig med Lornsens forslag om en landsomfattende petitionsbevægelse, men kunne tilslutte sig tanken om, at hertugdømmerne statsretsligt set skulle betragtes som en enhed. Han deltog ivrigt i den nationalpolitiske debat og reagerede 1838 på en aviskritik imod de bondevalgte stænderdeputeredes manglende viden og ringe borgerlige dannelse ved at foreslå og arbejde for, at der skulle oprettes en borgerlig højskole for at afhjælpe problemet. Det er interessant, at denne skole blev oprettet $\mathrm{i}$ Rendsborg med Klenze som særdeles aktiv støttefigur, selvom højskolen ikke helt fik det påtænkte præg af en bondehøjskole. Men den kom altså to år før Rødding Højskoles oprettelse i 1844.

Til slut i Politiske Betragtninger kommer Grundtvig ind på begivenhederne i 1660 og enevælden som en samfundspagt mellem konge og folk - det sidste repræsenteret ved alle stænders tilslutning (jvf. ovenfor XII og XIV). Det centrale var, at parterne havde haft »Tillid til Guds Forsyn « [66], som man stadig kunne have [68]. Alt havde således udviklet sig på bedste måde i kærlighed til det »fælles Bedste« [67]. For at folkets stemme kunne nå de styrende, måtte 
trykkefriheden dog afklares bedre, end den var i 1830, så skribenterne mere sikkert vidste, hvor de stod (jvf. X ovenfor, frihed).

\section{Debat og skriftets virkninger}

Grundtvigs 1831-skrift blev i samme år genoptrykt og oversat til tysk, hvilket i sig selv begrunder, at det faktisk blev taget alvorligt $i$ den fremvoksende offentlige, politiske debat. Det stigende politisksamfundsmæssige engagement i videre kredse belægges også af interessante breve fra 1830/31 i Danske politiske breve, I, s. 1-25.

Udviklingen gik stærkt, næsten dag for dag skete der nyt. Det holstenske ridderskab havde med flid mislæst proklamationen fra midt i november 1830 (Lornsens fængsling) om konstitutionelle forandringer og havde til kongen sendt en skrivelse, hvori ridderskabet takkede for muligheden af en fællesforfatning for hertugdømmerne. Kongen svarede 4. december, at det skulle de ikke gå ud fra. 11. og 13. januar 1813 besluttede regeringen (offentliggjort 21 . februar), at der skulle arbejdes hen mod flere sideordnede stænderinstitutioner, for kongeriget og for Slesvig og Holsten, hver for sig. Antagelig med baggrund i Preussens stænderanordning fra 1823 ville der blive tale om en rådgivende funktion for disse forsamlinger.

Den liberale officer A.F. Tscherning udarbejdede manuskript til et modsvar til Lornsens skrift. Udkastet blev aldrig trykt, men cirkulerede fra 24.11. 1830 til kommentar hos andre liberale. Oberstløjtnant, J.N.B. Abrahamsons svar findes (Da. pol. Breve, I, 7-9), og viser en klar opfattelse af, at Slesvig burde have sin egen forsamling og ikke skulle knyttes for tæt til Holsten, men f. eks. burde have fælles højesteret med Danmark. Sprogligt burde f. eks. retsvæsenet fungere på tysk for tysktalende og på dansk for dansktalende - men hvad med friserne, færingerne, vestindierne m.v. sprogligt set, spurgte Abrahamson.

I følge Sønderjyllands Historie, IV, s. 176f. virkede Grundtvigs skrift som den direkte anledning til den dansksindede kielerprofessor Chr. Paulsens senere indflydelsesrige fremlæggelse fra 1832 om folkelighed og statsret i Slesvig, »Volksthümlichkeit und Staatsrecht des Herzogthums Schleswig «. Heri blev sprog- og folkegrænserne for Slesvigs ca. 330.000 indbyggere søgt fastlagt, som en forudsætning for rimelige reformer af styret, jvf. kortet ovenfor. Statsretligt burde 
Slesvig hverken knyttes nærmere til Holsten eller Danmark, hvorimod helstaten burde udvikles $\phi$ konomisk ved først at skabe fælles mønt og indre toldfrihed.

Stilistisk og dispositionsmæssigt virker det, som om Grundtvig med Politiske Bemærkninger har slået tre hastigt skrevne kladder om politik sammen med en fjerde aktuel om Slesvig for at kunne få indflydelse på debatten og den konstitutionelle udvikling inden disse havde lagt sig i for faste spor.

\section{Afslutning}

I tiden fra 1831-49 udviklede Grundtvig med stigende klarhed sine politiske og folkelige friheds- og samfundstanker under »Guds Forsyn «, således som mange sider af dette er belyst gennem forskningen. Det interessante har her været, at mange af de vigtige af hans senere mere udviklede opfattelser kom til udtryk i 1831-skriftet. De fleste anskuelser havde en forhistorie hos ham, i 1830 blev de sat i et indbyrdes vekselvirkningsforhold. Skønt englandsopholdene 1829-31 var vigtige som katalysatorer, så var den danske og europaiske situation $\mathrm{i}$ oprørsåret $1830 \mathrm{og}$ det tidligere tankegods nok ligeså væsentlige for hans samfundsmæssige og politiske tænkning og aktivitet derefter. Målsætningen fra 1827s Testamente, om ikke at blande for meget sammen, blev ikke opnået i 1831-skriftet; men f.eks. argumentationen om det repræsentative demokratis problemer i afsnittet om rigsdage står i den forstand klart. Det engelske Parlament er trods alle reformer den dag i dag ofte et ringe udtryk for »folkets stemme« og står mere for et majoritetsvaelde, der kan have svært ved at tilgodese hele folkets velfærd. Set $\mathrm{i}$ historiens bakspejl må Grundtvig medgives, at den danske oplyste enevælde sidst i 1700-tallet, mere end på hans egen tid, set i europæisk perspektiv, var en for det almene velfærd særdeles velfungerende styreform.

Som engageret i og med ønske om offentligt at påvirke samfundsudviklingen, både kulturelt og statsligt, var Grundtvig blandt meget andet også politiker, mange år før han i 1848 gik ind i parlamentarisk politik.

Det centrale før og især omkring og efter 1831-skriftet var for Grundtvig at fremlægge og virke for en historisk og pragmatisk 
grundet styreform til gavn for hele folkets velfærd, hvor frihed og magt afbalancerede hinanden, hvor de styrende var lydhøre overfor et borgerligt oplyst folks stemme, og hvor tillid, kærlighed og ansvarsbevidsthed mere end egenkærlighed og mistillid var bestemmende mellem samfundsmedlemmerne indbyrdes og for hele folkets fremadrettede handlinger - alt under Guds forsyn.

Mere kynisk tænkende mennesker idag ville beskrive Grundtvigs projekt som et drømmesyn, der ikke var af denne verden. I en lige offentliggjort og særdeles grundig rapport fra Århus Universitet om livskvalitet og om bl.a. danskernes politiske og samfundsmæssige holdninger fremhæves det, at danskerne er velorienterede statsborgere og ikke kun drives af egennytten. Det opsummeres som en slags »nationalt portræt $\aleph^{31}$ :

»Den danske befolkning er,

a en politisk bevidst befolkning, der klart og hurtigt opfatter de hovedbegivenheder, der sker $\mathrm{i}$ verden omkring sig og på Christiansborg.

a en samfundsmæssig ansvarlig befolkning, der på det politiske plan kan erkende landets situation, og som er villig til på det personlige plan at tage konsekvensen heraf, bl.a. i form af offervillighed og skattebyrder. Myten om den »uansvarlige vælger « gælder derfor ikke i Danmark.

a en befolkning, der er villig til i krise-og modgangstider at give afkald.

a en befolkning der også trives i modgang, som under de $\varnothing$ konomiske tilbagegangstider i 1980'erne.

a en overordentlig arbejdsom befolkning, der er villig til at påtage sig over- og ekstaarbejde til trods for det eksisterende skattesystem.

a en besindig og mådeholden befolkning.

a og en befolkning, der er krisevant, og hvis stærkeste sider synes at komme frem i modgang.«

Så måske tænkte den gamle slet ikke så skævt endda. 
Noter

1 Om Grundtvigs økonomiforståelses sammenhæng med hans politikforståelse, Wåhlin, Grundtvigs økonomiske tænkning, 1990, samt den brede henvisning dér til kildesteder og faglitteratur. Vedr. politikforståelsen er jeg inspireret af E. Rasmussen, Politik, s. 14, jvf. hans udbygning heraf i, Komparativ politik, I-II.

2 Grell, England, s. 108; Fl. Lundgreen-Nielsen, Grundtvig og danskhed, s. 25-26.

3 Jens Arup Seip, Den opinionsstyrte enevelde, 1950.

4 Digtet skrevet til 28.maj-festen 1839 på årsdagen for det kgl. løfte af 1831 om de kommende stænderforsamlinger; tekst bl.a. i Gr. Udvalgte Værker, I, s. 371-72.

5 Jvf. litteraturlisten og bibliografiske data dér.

6 Valgret og valgbarhed til Stænderforsamlingerne blev fastlagt således ud fra brugsstørrelser og indkomst, at en vis jordbesiddelse var grundlaget, så at de fleste gårdmænd (også fæstere) og dermed ligestillede med over én tønde hartkorn skatteværdi havde del i de politiske rettigheder. I 1849 udvidedes valgret endog til næsten alle familiefædre over 25 år med egen husstand, mens valgbarhed i visse sammenhænge krævede solidere status. Alle de forfatningsmæssige love fra Kongeloven over 1831-løftet til stænderanordningen 1834 og grundloven 1849 med senere ændringer findes i Himmelstrup, Danske forfatningslove. Den vigtigste af lokalstyreanordningerne (1837-41), Landkommunalloven af 1841 om kommuner og amter findes i Collegial-Tidende, 1841, s. 680 ff. De komplicerede forhold omkring politiske rettigheder, Rerup, Folkestyre, 1992, s. 352 f.

7 Om de socio- $\varnothing$ konomiske forhold som baggrund for Grundtvigs gennemslagskraft (gårdmandsklassen), Wåhlin, Gr.s økon. tænkning, 1990, s. 261 f.

8 De statsteoretiske opfattelser af »naturretstilstand «, folkesuverænitet og samfundskontrakt efter Schmandt, Politiska Ideernas hist. s. 166f., 244f. Grundtvigs forudsætninger i væsentlige dele af den engelske »whig«-interpretation (især John Locke) efter Kaae,»Ikkun som voksne menneskebørn «, 1986. Vedr. parallellerne til den konservative engelske linje hos Grundtvig, især Edm. Burkes opgør med teoretisk fornuft og den franske revolution, se 
Schmandt, 302ff. Derved bliver der ikke så meget tilbage af den nyere (dvs. 1800-1850) liberalisme i politisk tænkning (men derimod klart i økonomisk) hos Grundtvig. Jeg må heri følge L. Kaae, s. 75-76 i hans se kritik af Baagøs opfattelse fra 1955 om Grundtvigs relation til den »nyere« engelske liberalisme, 1955. Hobbes efter Stybe, Hobbes; politiske teorier i $\emptyset$ vrigt efter Stybe, Politiske ideologier (1972) og Sv. Clausen, Danske Statsteorier (1953), samt Schmandt.

9 Lundgreen-Nielsen, Grundtvig og danskhed, s. 173; Wåhlin, 1986, s. 15 16; Wåhlin, Grundvigs økonomiske tænkning, s. 291.

10 Grell, England, anfører s. 18 og 20, hvorledes det fra 1814-15 bliver stadig klarere for Grundtvig, at et egentligt »folk« må være sig sin sproglige og historiske egenart bevidst, og må have et åndeligt mål - i kristen forståelse - for placeringen i hele menneskehedens historie.

11 Lundgreen-Nielsen, Danskhed, s.14-15. Grundtvig skifter datering for sin opvågnen til danskhed fra 1807 (Københavns bombardement) til 1816 ved læsning af Rimkrøniken.

12 Khimære, græsk fabeldyr, må vel her tages i sin videre betydning som fantasifoster.

13 Om det sene 1700-tals patriotisme, Dansk Identitetshistorie, bind 1 og 2. Thomas Thaarups (1749-1821) syngespil »Høstgildet« (1790) og utallige lejlighedsviser slog vitterligt bredt an i befolkningen med deres 4 grundtemaer: Kongetroskab, fædrelandskærlighed, Gudstro, og kærligheden mellem mand og kvinde,- jævnfør f.eks. K.L. Rahbeks forord til 1822 udgaven af Thaarups skrifter; jvf. bl.a. »Fødelands-Kjærlighed« (1782) 6. strofe: »De danske Sletter, Norges Fjælde/ Har Minder af den Kjærlighed,/ Hvorpaa Monarchers sande Vælde,/ Staar fast i Feide og i Fred./ Kiær har vi Fædre, Ven og Pige/ Og Frugten af arbeidsom Haand;/Men overalt skal Flammen stige,/ som brænder for vort Fødeland!«

14 1. strofe, In. 1: »De Snekker mødtes i Kvæld paa Hav« kunne (næsten) ligeså godt have lydt: »Orlovsmænd mødtes til kamp på hav« - men derved ville netop de gamle nordiske ord »snekker« og »Kvæld« - og dermed den oldnordiske tone - ikke fra starten være slået an.

15 Thaarup var lejlighedsdigter, men demonstrerede også vitterlige litterære kvaliteter, f.eks. ved teksten til Frihedsstøtten. 
16 Willemoesdigtet blev først offentliggjort sept. 1810 i K.L. Rahbeks »Danske og Norske historiske Mindesange« under overskriften »Kiekheds Erindring, Willemoes « genoptrykt med rettelser 1815 af Grundtvig i »Kvædlinger«. Nærmere om tolkning af Willemoes-digtet, G. Albeck, 1934, s. 524.

17 Grell, England, s. 14 henviser til andre skrifter og digte fra o. 1811, hvor tonen over for England er mere barsk, men alligevel beskriver Grell relationen som »overraskende afdæmpethed «.

18 I forsvarsordningen for Danmark-Norge stillede Norge med ca. to trediedele af matroserne, Jeppesen, Matroser, 1981. Dannebrog med split var orlogsflaget og nævnes i sangen. Først omkring Treårs-krigen tog bredere kredse af befolkningen Dannebrog til sig som nationalt symbol. Splitflaget forblev statslige institutioners og flådens flag.

19 Allerede 1809 og 1811 svingede Grundtvigs følelser for Norge, selvom han også ind imellem viste beundring for landet og folket, jvf. Lundgreen-Nielsen, Grundtvig og danskhed, s. 16.

20 Jeg har ingen forklaring på udeladelsen af kongen, da Grundtvig jo ellers er enevældens mand. En del kritik omkring kongens ansvar vedrørende de store nationale ulykker kan ligge i »dolkestødslegenden« om et svigt overfor flåden 1801, Feldbæk, „Dolkestødslegenden«. Måske ligger der i strofe 16 en antydning og kritik af, at flåden ikke havde fået rimelige vilkår.

21 Lundgreen-Nielsen, Danskheden, s. 21, anfører, at skriftet ingen opmærksomhed vakte i København, bl.a. fordi Grundtvig af den akademiske elite blev anset for utilregnelig. En analyse af Waterloo-slaget viser, at kun et par timers forskel i den preussiske armes fremmarch helt ville have ændret resultatet af slaget.

22 Grell, England, s. 23, viser ud fra Grundtvigs Verdenskrønike, 1817 (s. 611-12), at England er truet, fordi det har »givet Slip paa sine Fædres Sprog og Aandelige Smag«.

23 Lundgreen-Nielsen, Danskhed, s. 20-21; Grell, England, s. 18-19; Grundtvig, Europa, s. $92-94$ og 169 m.fl.st.

24 Grell har først i »Skaberordet og billedordet« (1980) og senere i »Skaberånd og folkeånd « (1988) s. 112f nærmere begrundet forbindelsen hos Grundtvig mellem det guddommelige og folkeligheden, herunder naturligvis dens sammenhæng med danskheden. Grundtvig herom i »Danne-Virke«, II, 
s. 118, »Om Mennesket i Verden«, hvor menneskesyn og »folk« sammenknyttes.

Begtrup, Udvalgte skrifter, III, 317; jvf. også L. Kaae, s. 77.

Begtrup, Udvalgte Skrifter, V, første citat s. 46-47, andet citat s. 82-83. Grell, England, s. 26-27, kommer nærmere ind på relationerne til engelske forhold.

27 Grundtvig er allerede tidligere kritisk overfor den engelske forfatning og parlamentet, Danne-Virke, IV s. 391. Grell, England s. 22-25 viser, hvorledes Grundtvig svinger mellem skarp kritik af og beundring for engelsk samfundsliv og historie.

28 Grell, England s. 90-97, gennemgår det væsentllige i tidsskrift-debatten om University College, som Grundtvig har kendt til.

29 Jvf. artiklen om C.F.H. Klenze i Biographisches Lexikon für SchleswigHolstein und Lübeck, bd. 9, 1991 s. 176-79.

30 Dansk Biografisk Leksikon, 2. udgave, bind XIV, s. 482-86, jvf. Sønderjyllands Historie, bd. 4, s. 158f. Lornsens hovedtanker gik ud på, at en provisorisk forsamling af alle stænder skulle udarbejde en fælles forfatning for hertugdømmerne med: 1) Et et-kammersystem efter norsk mønster (der siden deltes i 1. og 2. kammer); 2) Kamrene havde skattebevillingsret og lovgivende myndighed; 3) Absolut veto for kongen; 4) Styrelsen blev forlagt fra København til hertugdømmerne og administrationen skulle skilles fra retsplejen; 5) Fælles højesteret for hertugdømmerne; - alt således at Danmark og hertugdømmerne havde »kun Konge og Fjende tilfælles«.

31 Rapport fra Psykologisk institut, Aarhus Universitet, projektleder lektor Jørgen Goul Andersen, Statskundskab, AU - præsenteret i Jyllands-Posten $13 / 81994$, s. 5. 
Litteraturliste (se i øvrigt noterne)

»Anordning --- om Communalforfatning«, 28/8 1841, Collegial-Tidende. 1841, s. $680-756$

Albeck, Gustav: »N.F.S. Grundtvigs Digning om Peter Willemoes«, Fem danske Studier tilegnet Vilhelm Andersen (Studier fra Sprog- og Oldtidsforskning, XLIV, Nr. 167) Kbh. 1934, s. 5-24.

Bang, J.P.: Grundtvig og England. Studier over Grundtvig. Kbh. 1932.

Bekker-Nielsen, T. (red.): Ikke stykkevis og delt - 5 essays om Grundtvig og grundtvigianisme. Århus. 1986.

Baagø, Kaj: »Grundtvig og den engelske liberalisme«, Grundtvig-Studier. 1955, s. 7-37.

Collegial-Tidende, Ny, bd. 42. Kbh. 1841.

Dag- og Udtogsbøger, N.F.S. Grundtvig, I-II, ved Gustav Albeck. Kbh. 1979.

Dam, Poul: Politikeren Grundtvig. Århus. 1983.

Damsholt, Tine: »Kongehånd og folkestemme. Grundtvig og den opinionsstyrede enevælde«, Nornesalen, forskning 1992-93, udg. af Forskningscenter for folkelig livsoplysning. 1993, s. 52-60.

Damsholt, Tine: Troen på Folkeviljen. Analyse af en tradition i dansk demokratiopfattelse i de sidste 200 år. Krogs forlag. 1994.

Danske politiske Breve fra 1830erne og 1840erne, I-IV. Kbh. 1945-1955.

Feldbæk, Ole: »De danske søofficerer og »dolkestødslegenden « om slaget på Reden«, Fortid og Nutid. 1983, s. 27-42.

Grell, Helge: Skaberånd og Folkeånd. En undersøgelse af Grundtvigs tanker om folk og folkelighed og deres forhold til deres kristendomssyn. Århus. 1988.

Grell, Helge: England og Danmark. Århus. 1990.

Grundtvig, N.F.S.: Mands Minde 1788-1838. Foredrag over det sidste halve Aarhundredes Historie holdte 1838, ved Svend Grundtvig. Kbh. 1877. 
Harrison, Wilfrid: Sources in British Political Thought 1593-1900. London/N.Y. 1965.

Heritage and Prophecy. Grundtvig and the English-Speaking World, A.M. Allchin, D. Jasper, J.H. Schørring, and K. Stevenson, eds. Århus. 1993.

Himmelstrup, Jens og Møller, Jens: Danske Forfatningslove 1665-1953, 2. udg. Kbh. 1970.

Hobsbawm, E.J.: The Age of Revolution, 1789-1848 (1962). London. 1973.

Jeppesen, Hans: Matroser til den dansk-norske flåde (Norsk sjøfartsmuseum). 1981.

Klenze, Carl Fr. Herrmann: Ueber das Verfassungswerk von Schleswig-Holstein, eine Beleuchtung der Schrift des Herren Canzeleirath und Landvogts U.J. Lornsen ueber denselben Gegenstand. Altona. 1830.

Kaae, Lars: »Ikkun som voxne Menneske-Børn: Grundtvig og frihed «, Stykkevis og delt, T. Bekker-Nielsen, red. Århus. 1986, s. 75-122.

Locke, John: Second Treaties of Civil Government (World Classic Edition). Oxford. 1947.

Lornsen, Uwe Jens, Ueber das Verfassungswerk in Schleswigholstein. Kiel 1830 .

Lundgreen-Nielsen, Flemming: »Grundtvig og danskhed«, Dansk identitetshistorie (O. Feldbæk, red.), bd. 3. Kbh. 1992, s. 9-187.

Madvig, J.N.: »Et Bidrag til historisk Belysning af Tanken om Slesvigs Deling som Løsning af den dansk-slesvigholstenske Strid «, Historisk Tidsskrift, 5. rk., bd. IV. 1888, s. 316-374.

Møller, Erik: »Grundtvig 1848-50«, Grundtvig-Studier. 1950, s. 57-95.

N.F.S. Grundtvigs Breve til hans Hustru under Englandsrejserne 1829-31, udg. af hans Børnebørn (Stener Grundtvig og Vilhelm Grundtvig). Kbh. 1920.

Paulsen, P.D. Christian: Ueber Volksthümlichkeit und Staatsrecht des Herzogthum Schleswigs; nebst Blicken auf den ganzen Dänischen Staat. Kiel 1832. 
Rahbek, K.L.: Danske og Norske historiske Mindesange. Kbh. 1810.

Rerup, Lorenz: »Folkestyre og danskhed. Massenationalisme og politik 18481866«, Dansk identitetshistorie, bd.3. Kbh. 1992, s. 337-442.

Seip, Jens Arup: »Teorien om det opinionsstyrte enevelde«, (norsk) Historisk tidskrift, bd. 38. 1958.

Sønderjyllands Historie, Vilh. laCour et al. red., bd. IV, 1805-1864, ved Knud Fabricius. Kbh. U.å. (1937)

Thaning, Kaj: »Grundtvig og den grundlovgivende Rigsforsamling «, Grundtvig-Studier. 1949, s. 35-73.

Thyssen, Anders Pontoppidan: »Vækkelse, kirkefornyelse og nationalitetskamp i Sønderjylland 1815-1850«. Åbenrå 1977. Vakkelsernes frembrud i Danmark i første halvdel af det 19. århundrede. Red.: A.P. Thyssen. VII bind og: Skrifter, udgivne af Historisk Samfund for Sønderjylland nr. 46.

Wåhlin, Vagn: »Ikke stykkevis og delt«, Stykkevis og delt (T. Bekker-Nielsen, red.). Århus. 1986, s. 9-52.

Wåhlin, Vagn: „Grundtvigs økonomiske tænkning«, Grundtvig-Studier. 1989/90, s. 246-302.

Wåhlin, Vagn: »Denmark, Slesvig-Holstein and Grundtvig in the 19th Century«, Heritage and Prophecy. Århus. 1993, s. 243-270. 